Review

\title{
Zinc in Early Life: A Key Element in the Fetus and Preterm Neonate
}

\author{
Gianluca Terrin ${ }^{1, *}$, Roberto Berni Canani ${ }^{2}$, Maria Di Chiara ${ }^{1}$, Andrea Pietravalle ${ }^{1}$, \\ Vincenzo Aleandri ${ }^{1,3}$, Francesca Conte ${ }^{4}$ and Mario De Curtis ${ }^{4}$ \\ Received: 8 August 2015; Accepted: 26 November 2015; Published: 11 December 2015 \\ 1 Department of Gynecology-Obstetrics, University of Rome La Sapienza, Rome 00186, Italy; \\ mariadc91@hotmail.it (M.D.C.); apietravalle@gmail.com (A.P.); vincenzo.aleandri@uniroma1.it (V.A.) \\ 2 Department of Translational Medicine, University of Naples Federico II, Napoli 80138, Italy; \\ berni@unina.it \\ 3 Research Center on Evaluation of Quality in Medicine-CEQUAM, University of Rome La Sapienza, \\ Rome 00186, Italy \\ 4 Department of Pediatrics, University of Rome La Sapienza, Rome 00186, Italy; frconte2000@yahoo.it (F.C.); \\ mario.decurtis@uniroma1.it (M.D.C.) \\ * Correspondence: gianluca.terrin@uniroma1.it; Tel.: +0039-064-997-2536
}

\begin{abstract}
Zinc is a key element for growth and development. In this narrative review, we focus on the role of dietary zinc in early life (including embryo, fetus and preterm neonate), analyzing consequences of zinc deficiency and adequacy of current recommendations on dietary zinc. We performed a systematic search of articles on the role of zinc in early life. We selected and analyzed 81 studies. Results of this analysis showed that preservation of zinc balance is of critical importance for the avoidance of possible consequences of low zinc levels on pre- and post-natal life. Insufficient quantities of zinc during embryogenesis may influence the final phenotype of all organs. Maternal zinc restriction during pregnancy influences fetal growth, while adequate zinc supplementation during pregnancy may result in a reduction of the risk of preterm birth. Preterm neonates are at particular risk to develop zinc deficiency due to a combination of different factors: (i) low body stores due to reduced time for placental transfer of zinc; (ii) increased endogenous losses; and (iii) marginal intake. Early diagnosis of zinc deficiency, through the measurement of serum zinc concentrations, may be essential to avoid severe prenatal and postnatal consequences in these patients. Typical clinical manifestations of zinc deficiency are growth impairment and dermatitis. Increasing data suggest that moderate zinc deficiency may have significant subclinical effects, increasing the risk of several complications typical of preterm neonates (i.e., necrotizing enterocolitis, chronic lung disease, and retinopathy), and that current recommended intakes should be revised to meet zinc requirements of extremely preterm neonates. Future studies evaluating the adequacy of current recommendations are advocated.
\end{abstract}

Keywords: micronutrients; neonate; newborn; fetus; low birth weight; growth; dermatitis; Necrotizing enterocolitis

\section{Introduction}

Zinc is one of the most abundant trace elements in humans [1]. Zinc is functional for the activity of a number of proteins (i.e., enzymes, membrane proteins, gene-regulatory proteins, and hormonal receptors) involved in most major metabolic pathways [2]. Zinc interacts with proteins in different ways: (i) by promoting enzymatic processes; (ii) by maintaining quaternary structure stability (Figure 1) [2]; or (iii) by favoring interactions with other molecules (i.e., proteins, nucleic acids) [3]. The six enzyme classes established by the International Union of Biochemistry Enzymes, 
i.e., oxidoreductases, transferases, hydrolases, lysases, isomerases and ligases, all require zinc [1]. During the enzymatic processes, zinc may have (1) a catalytic role (it has roles directly in catalytic processes), (2) a coactive role (by enhancing or diminishing catalytic functions) and a structural role (it is required for quaternary structure stability of enzymes) [4]. Metallothioneins (MTs) are the most abundant cysteine-rich proteins containing zinc [5]. These proteins have an important antioxidant activity and stabilize cell membranes only in the presence of zinc [6]. Zinc is also required for the DNA binding proteins involved in the regulation of gene expression [7-9]. The glucocorticoid and estrogen receptors are examples of zinc hormonal receptor proteins. They are members of a multigene family that includes receptors for thyroid hormone, retinoic acid, and vitamin D [10]. The DNA binding domain of these proteins contains zinc. Removal of this element yields hormonal receptors that do not bind DNA when activated by glucocorticoids or estrogens.
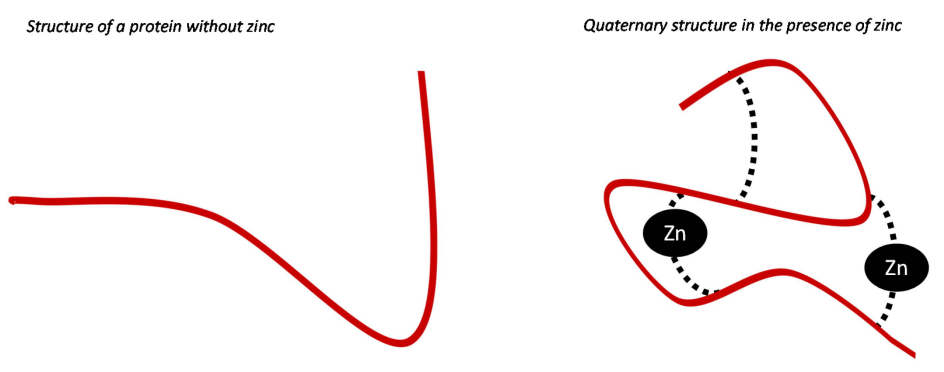

Figure 1. Zinc role in stabilizing protein quaternary structure [2].

The characteristic of the zinc is, certainly, its even distribution throughout the body. Functionally, zinc participates in cell division and growth, intestinal electrolyte absorption, neurotransmission, immune response, thymus activity, and vision (Figure 2) [11-17]. Consequently, numerous functions in humans are affected by zinc deficiency, particularly during periods of increased metabolism. However, clinical manifestations become evident only with severe deficiency; dermatitis, diarrhea, neurological disorders, growth failure, infections and delayed tissue healing following injuries are the most frequent clinical consequences of zinc deficiency. In early life, zinc deficiency may affect embryogenesis and may influence duration of pregnancy. After birth, a major factor associated with the development of zinc deficiency is its inadequate intake. Additional exacerbating factors include high physiological requirements, excessive losses by pathological conditions, intestinal failure and treatment with some drugs [18]. With some degree of variability, as with many other nutrients, human do not have functional reserves or body stores of available zinc, except neonates born at term, who may be able to draw on the hepatic zinc accumulated during the entire gestational period [19]. These aspects are of particular importance for preterm neonates. In this population, high requirements for growth and environmental injuries, physiological intestinal insufficiency and frequent use of antibiotics, significantly increase the risk of zinc deficiency. In addition, preterm birth reduces the duration of pregnancy and thus the amount of hepatic stores available during periods of reduced zinc intake.

Consequently, preservation of a positive zinc balance in the mother during pregnancy and lactation, and in neonates, is of critical importance in early life for the possible consequences on health, growth and development.

Starting from these considerations, we carried out a narrative review, analyzing current literature, with the subsequent aims to:

1. Explore the role of zinc in early life including embryogenesis, fetal and neonatal life.

2. Analyze the criteria used for the diagnosis of zinc deficiency in preterm neonates.

3. Investigate the consequences of zinc deficiency in preterm neonates.

4. Evaluate the adequacy of current recommendations on zinc for preterm neonates. 
5. Suggest new possible research perspectives on the use of zinc in early life.

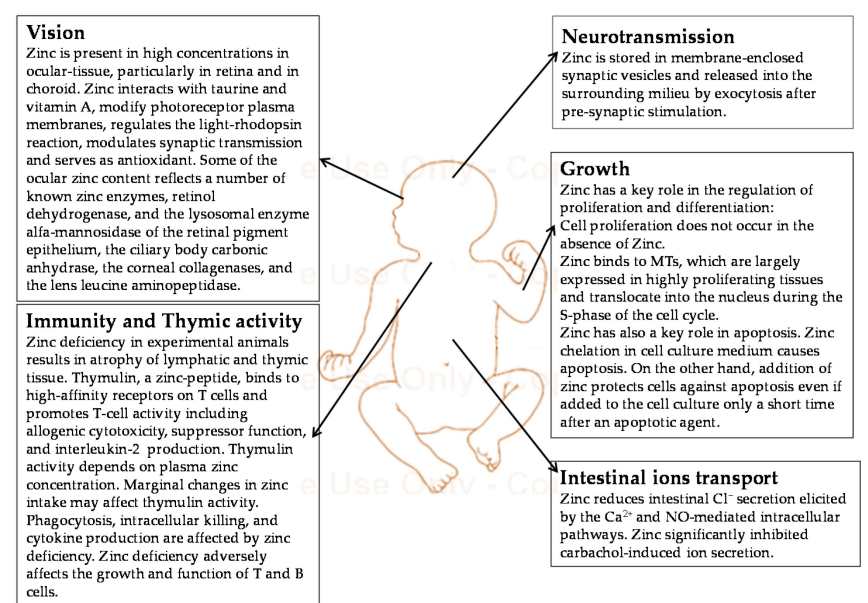

Figure 2. Zinc functions in early life [11-17].

\section{Evidence Selection Method}

We performed a systematic search of articles on the role of zinc in embryogenesis, during fetal life and in babies born prematurely. We conducted an electronic search in MEDLINE using the following medical subject headings and terms: "zinc" associated with "embryogenesis", "fetus", "preterm neonate" or "preterm newborn". In addition, we made a manual search of the reference lists of all eligible articles. We limited the search to clinical trials, case reports and reviews in human and animal model, in English language. We selected and analyzed 81 studies (Table 1) and report the results here in a narrative review.

Table 1. Evidence selection.

\begin{tabular}{cccc}
\hline $\begin{array}{c}\text { Medical Subject } \\
\text { Headings and Terms }\end{array}$ & $\begin{array}{c}\text { Zinc AND } \\
\text { Embryogenesis }\end{array}$ & Zinc AND Fetus & $\begin{array}{c}\text { Zinc AND Preterm Neonate or } \\
\text { Zinc AND Preterm Newborn }\end{array}$ \\
\hline Eligible articles & 196 & 100 & 155 \\
Excluded articles (reasons) & 188 (unrelated articles) & 86 (unrelated articles) & 96 (unrelated articles) \\
Selected articles, $n$ & $\mathbf{8}$ & $\mathbf{1 4}$ & $\mathbf{5 9}$ \\
-Human & $\mathbf{4}$ & $\mathbf{1 1}$ & $\mathbf{5 5}$ \\
-Animal & $\mathbf{4}$ & $\mathbf{3}$ & $\mathbf{4}$ \\
\hline
\end{tabular}

\section{Function of Zinc during Fetal and Neonatal Life}

\subsection{The Role of Zinc in Embryogenesis}

An adequate supply of maternal zinc is essential for embryogenesis. A major role of zinc is the regulation of chromatin structure and function and, thus, the expression of genes essential for embryogenesis [20]. Consequently, insufficient quantities of zinc during embryogenesis may influence the final phenotype of all organs [21]. Maternal zinc deprivation increases the risk of fetal mortality, growth retardation and malformations, including neural tube defects as demonstrated in clinical trials [22-24]. The vast majority of the evidence on the role of zinc in embryogenesis derives from the observation of the phenomenological effects of its deficiency in animal models rather than in human pregnancies (Table 2) [25-32]. Particular attention should be given to alcohol intake during pregnancy. Alcohol alters zinc metabolism and induces severe consequences on the fetus [33-39] Many of the clinical manifestation typical of the alcoholic fetal syndrome may be specifically related to zinc deficiency [33-39]. 
Table 2. The role of zinc in embryogenesis. Evidence from animal and human studies.

\begin{tabular}{|c|c|c|c|}
\hline \multicolumn{4}{|c|}{ A. Evidence from Experimental Animal Model. } \\
\hline Study & Model & Study Design & Main Results \\
\hline $\begin{array}{l}\text { Hurley et al., } \\
1969 \text { [25] }\end{array}$ & Pregnant rats & $\begin{array}{l}\text { Severe zinc deficiency induced by the use of a diet } \\
\text { containing isolated soybean protein (treated with a } \\
\text { chelating agent). Controls fed with } \\
\text { zinc-supplemented diet }\end{array}$ & $\begin{array}{l}98 \% \text { of full-term fetuses with congenital } \\
\text { malformations of the tail }(72 \%) \text {, finger }(64 \%) \text {, } \\
\text { lungs }(54 \%) \text {, palate }(42 \%) \text {, brain }(47 \%) \text {, eye } \\
(42 \%) \text {, feet }(38 \%) \text {, urogenital tract }(21 \%)\end{array}$ \\
\hline $\begin{array}{c}\text { Hicory et al., } \\
1979 \text { [26] }\end{array}$ & Pregnant rats & $\begin{array}{l}\text { Eighteen rats fed with zinc deficient diet and } 18 \text { fed } \\
\text { with zinc supplemented diet during pregnancy }\end{array}$ & $\begin{array}{l}\text { Malformations of the trunk and limbs in fetuses } \\
\text { of zinc deficient mothers }\end{array}$ \\
\hline $\begin{array}{l}\text { Rogers et al., } \\
\quad 1985 \text { [27] }\end{array}$ & $\begin{array}{l}\text { Long-Evans hooded pregnant } \\
\text { rats and fetuses }\end{array}$ & $\begin{array}{l}\text { Determination of teratogenicity of maternal } \mathrm{Zn} \\
\text { deficiency in the Long-Evans hooded rat, } \\
\text { examining the effects of } \mathrm{Zn} \text { deficiency on } \mathrm{Zn}, \mathrm{Fe} \text {, } \\
\text { and } \mathrm{Cu} \text { concentrations in maternal and fetal } \\
\text { tissues. Evaluation of the effects of } \mathrm{Zn} \text { deficiency } \\
\text { on the risk of abdominal and skeletal } \\
\text { malformations }\end{array}$ & $\begin{array}{l}\text { All fetuses presented malformations when zinc } \\
\text { was supplemented at low doses }\end{array}$ \\
\hline $\begin{array}{l}\text { Falchuk et al., } \\
\quad 2001[28]\end{array}$ & Frog embryos & $\begin{array}{l}\text { Deprivation of zinc in embryos to evaluate the } \\
\text { effects on metallo-proteins activity and on organ } \\
\text { formation and development }\end{array}$ & $\begin{array}{l}\text { Agenesis of dorsal organs (including brain, } \\
\text { eyes and spinal cord) in embryos developed in } \\
\text { the absence of zinc. }\end{array}$ \\
\hline \multicolumn{4}{|c|}{ B. Evidence from Clinical Studies in Human. } \\
\hline Study & Population & Study Design & Results \\
\hline $\begin{array}{l}\text { Velie et al., } \\
1999 \text { [29] }\end{array}$ & $\begin{array}{l}\text { Mothers of infants with neural tube } \\
\text { defect (NTD) compared with mothers of } \\
\text { healthy neonates (controls) }\end{array}$ & $\begin{array}{l}\text { Retrospective study on pre-conceptional use of } \\
\text { vitamin, mineral, and food supplements, by filling } \\
\text { a specific questionnaire }\end{array}$ & $\begin{array}{l}\text { Risk of NTDs decreased with the increase in } \\
\text { maternal pre-conceptional zinc intake }\end{array}$ \\
\hline $\begin{array}{l}\text { Cengiz et al., } \\
2004 \text { [30] }\end{array}$ & $\begin{array}{l}\text { Mothers of infants with neural tube } \\
\text { defect diagnosed in the second trimester } \\
\text { of gestation compared with mothers of } \\
\text { healthy neonates (controls) }\end{array}$ & $\begin{array}{l}\text { Case-control study to investigate the relationship } \\
\text { between maternal micronutrient serum level } \\
\text { (including zinc) and NTD occurrence in neonates }\end{array}$ & $\begin{array}{l}\text { No strict correlation between zinc } \\
\text { concentrations and NTD }\end{array}$ \\
\hline $\begin{array}{l}\text { Zeyreks et al., } \\
\quad 2009[31]\end{array}$ & $\begin{array}{l}\text { Mothers of infants with neural tube } \\
\text { defect (NTD) compared with mothers of } \\
\text { healthy neonates (controls) }\end{array}$ & $\begin{array}{l}\text { Case-control study to investigate the relation } \\
\text { between cord blood and maternal micronutrient } \\
\text { serum levels of (including zinc) and NTD } \\
\text { occurrence in neonates }\end{array}$ & $\begin{array}{l}\text { The mean maternal serum zinc level in mothers } \\
\text { of neonates with NTD was significantly lower } \\
\text { than those of controls }\end{array}$ \\
\hline $\begin{array}{l}\text { Dey et al., } \\
2010[32]\end{array}$ & $\begin{array}{l}\text { Mothers of infants with neural tube } \\
\text { defects (NTD) compared with mothers } \\
\text { of healthy neonates (controls). }\end{array}$ & $\begin{array}{l}\text { Hospital-based case-control study conducted with } \\
\text { the objective of finding the relationship between } \\
\text { serum zinc levels in newborns and their mothers } \\
\text { and NTDs in a Bangladeshi population }\end{array}$ & $\begin{array}{l}\text { NTD were more likely in subjects born from } \\
\text { mothers with lower serum zinc level }\end{array}$ \\
\hline
\end{tabular}




\subsection{Metabolism of Zinc in Fetal Life}

Most fetal zinc accretion occurs after the 24th week of gestation [40]. As gestation progresses, fetal zinc concentrations constantly increase [3]. Zinc is stored in the fetal liver, [3] and transport and accumulation of zinc in the liver is mediated by MTs. Induction of hepatic MTs activities results in hepatic zinc accumulation.

In the last trimester, the mother transfers to the fetus up to $1.5 \mathrm{mg} / \mathrm{Kg}$ of zinc every day [41].

Placental transfer of zinc to the fetus is mediated mainly by an endocytic mechanism [42]. Affinity for zinc by the placenta does not vary with gestational age or with low maternal plasma zinc concentrations. Zinc deficiency in the fetus is observed only in the presence of severe maternal zinc deficiency, because placental transfer of this element is an active process and fetal zinc concentrations are maintained constantly higher than maternal levels [41]. On the other hand, the absence of a ready mechanism for adjusting possible fetal zinc deprivation reduces the effects of maternal zinc supplementation during pregnancy.

Evidence from rodent models and humans suggests that maternal zinc restriction during pregnancy influences fetal growth and health [25]. In humans, conflicting results have been obtained when this relation has been explored. A recent Cochrane meta-analysis, including 21 randomized controlled trials involving over 17,000 women, demonstrated that maternal zinc supplementation during pregnancy resulted in a reduction in preterm birth (risk ratio $0.86,95 \%$ confidence interval 0.76-0.97) [43]. No clear benefit of zinc supplementation was demonstrated on many other maternal and neonatal outcomes, except for induction of labor in a single trial. On basis of their results, the authors suggest that since the preterm association could well reflect poor nutrition, studies to address ways of improving the overall nutritional status of populations in impoverished areas, rather than focusing on micronutrient and or zinc supplementation in isolation, should be considered as priority. However, many important aspects should be considered during the interpretation of the results of meta-analyses. The evidence for reduction in preterm birth was primarily demonstrated in trials involving low-income women. In some of these trials, women were also given other micronutrients (i.e., iron, folate, vitamins or a combination of these). Risk of bias was high or unclear for many studies included in the analysis. Finally, the effects of maternal zinc supplementation on neonatal morbidities and long-term growth and neurodevelopment were investigated only in a small number of trials, reporting conflicting results [43]. However, consistent evidence has shown that maternal zinc supplementation starting in the second trimester and discontinued at delivery is associated with decreased infectious diseases during the first six months of infancy, presumably as a consequence of a positive effect of zinc on the immune response in early life [44].

Further studies may be useful to establish whether isolated zinc deficit may have consequences on otherwise well-nourished women and whether specific supplementation, in these cases, could improve fetal and neonatal short and long-term outcomes.

Specific diet regimens may increase the risk of zinc deficiency in women [45-47]. Table 3 reports different risks deriving from low zinc intake in women, according to diet regimen [45-47]. The current understanding of zinc homeostasis indicates that the primary determinants of zinc absorption are the amounts of ingested phytate, other than zinc [45-47]. High consumption of phytate reduces zinc absorption. The diet regimen should be monitored in pregnant women, to reduce the risk of zinc deficiency. 
Table 3. Risk magnitude of zinc deficiency during pregnancy according to maternal diet [45-47].

\begin{tabular}{cl}
\hline Risk of Zinc Deficiency & Diet Characteristics \\
\hline Low & $\begin{array}{l}\text { Adequate protein content mainly from non-vegetable sources (i.e., meat or } \\
\text { fish), low cereals intake (phytate intake }<500 \mathrm{mg} / \text { day) }\end{array}$ \\
\hline Moderate & $\begin{array}{l}\text { Mixed diet containing animal or fish protein, vegetarian or vegan diet not } \\
\text { based on cereal or flours (phytate intake of } 500-1500 \mathrm{mg} / \text { day) }\end{array}$ \\
\hline High & $\begin{array}{l}\text { Low animal protein intake, high unrefined, unfermented and } \\
\text { ungerminated * cereals intake (phytate intake }>1500 \mathrm{mg} / \text { day) }\end{array}$ \\
\hline
\end{tabular}

Note: * Germination of cereal grains or fermentation (e.g., leavening) of many flours can reduce antagonistic potency of phytates on zinc absorption.

\section{Neonatal Zinc Metabolism}

Zinc deficiency has been well documented in hospitalized premature neonates [48]. The risk of zinc deficiency increases in preterm and small for gestational age (SGA) neonates or in case of intestinal failure [49]. The high risk of deficiency derives from a combination of three main factors: (i) low body stores due to reduced time for placental transfer of zinc; (ii) potentially marginal intake, and (iii) increased endogenous losses. Intestinal zinc absorption is not regulated by zinc status, rather, it is absorbed as a percentage of intake. However, in term babies, zinc absorption improves with decreasing serum zinc concentration and zinc stores are mobilized, enabling infants to avoid clinical deficiency. Zinc content in human milk varies considerably $(0.7$ to $1.6 \mathrm{mg} / \mathrm{L})$ and declines with time [50-54]; while colostrum contains 8-12 mg/L, human milk at seven days of neonatal life contains $3-6 \mathrm{mg} / \mathrm{L}$ of zinc [50-54]. These values rapidly decrease at $1-3 \mathrm{mg} / \mathrm{L}$ at 1 month of life [50-54]. No clear differences in the zinc content of human milk were seen in women taking mineral supplements [50-54]. Preterm infant consuming $180 \mathrm{~mL} / \mathrm{kg}$ per day of supplemented human milk would receive only $0.5-1 \mathrm{mg} / \mathrm{kg}$ per day of zinc [50-54]. Formula milk concentration of zinc is 1.5-6 mg/L [50-54]. Despite the greater concentration of zinc in formulas, net absorption was significantly improved with human milk as compared with formulas (60\% vs. 20\%) [50-54]. Absorption is slightly decreased in fortified preterm human milk as a percentage, although net absorption increases [50-54]. Endogenous fecal zinc losses are estimated to range between 50 and $150 \mathrm{mcg} / \mathrm{kg}$ per day $[55,56]$. The gastrointestinal tract is the major site of zinc losses, resulting from the secretion of endogenous zinc into the lumen and subsequent excretion in the feces. The amount of zinc excreted in the feces could be considered as a pool of rescue that could be reabsorbed and used according to host zinc status. However, the amount of zinc reabsorbed may also be influenced by the occurrence of pathological condition such as diarrhea and steatorrhea $[55,56]$. Urinary excretion of zinc is high in extremely preterm neonates ( $35 \mathrm{mcg} / \mathrm{kg}$ per day) in comparison with at term babies [55,57]. In the absence of adequate supplementation, serum zinc concentrations decline rapidly during the first months of life (Figure 3) [58-61].

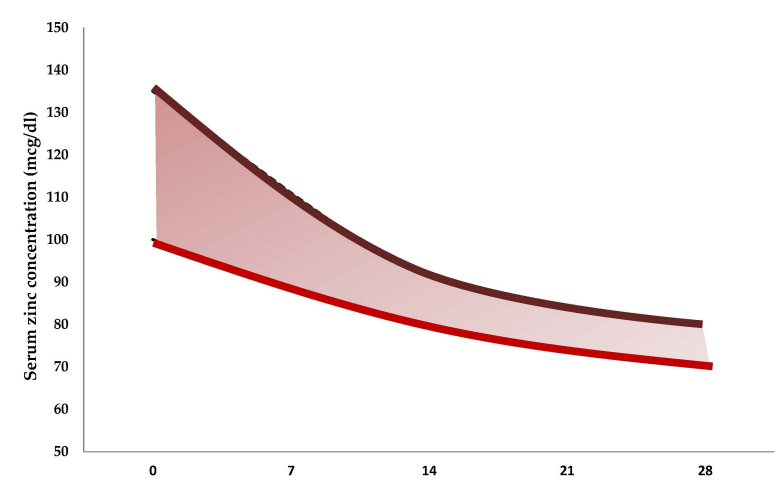

Figure 3. Serum zinc concentrations in preterm neonates by days of life [58-61]. 
A series of zinc transporter proteins (ZnT-1, ZnT-2, and ZnT-4) have been identified in the mammary gland [62]. In rare cases, the mammary gland may have a defect in the ZnT-4 gene, resulting in impaired secretion of zinc in breast milk. Breast milk zinc concentrations are below the normal range at all stages of lactation in these women [63]. Infants breast-fed by these mothers typically display the classic phenotype of acrodermatitis enteropathica already at approximately two months of postnatal age [63]. This syndrome has been described in term infants but is more likely to affect infants born preterm, suggesting an increased vulnerability of the preterm infant to clinically significant zinc deficiency syndromes [49]. Zinc concentrations in human milk may be influenced by vitamin A status, which regulates zinc transporters in the mammary gland (Table 4) [64-74]. In addition, the metabolism of zinc and vitamin A seems to be interrelated [72,74,75]. Severe vitamin A deficiency may reduce the absorption and lymphatic transport of zinc by altering synthesis of a zinc-dependent binding protein [75]. This aspect should be considered when zinc is supplemented in neonates receiving fortified human milk and multivitamin products containing vitamin A. These considerations suggest evaluating vitamin A supplementation, in addition to zinc supplementation, in neonates with evidence of zinc deficiency and in their mothers. However, the evidence of a strict zinc-vitamin A interaction in preterm neonates is still lacking.

Table 4. Mechanisms of the influence of other nutrients on zinc metabolism.

\begin{tabular}{cl}
\hline Nutrient & Mechanism \\
\hline \multirow{2}{*}{ Proteins [64-68] } & $\begin{array}{l}\text { Protein is a major source of zinc, thus increased protein intake results in } \\
\text { increased zinc intake } \\
\text { High amounts of protein in enteral nutrition improve zinc absorption } \\
\text { Casein in cow milk reduces zinc absorption }\end{array}$ \\
\hline Lipids [69] & $\begin{array}{l}\text { Fecal zinc increases in subjects with steatorrhea } \\
\text { Medium-chain triglycerides improve zinc absorption }\end{array}$ \\
\hline Copper [70] & $\begin{array}{l}\text { Slight increase in copper intake does not interfere with zinc absorption if } \\
\text { zinc intake is satisfactory. The effects of increased copper intake in } \\
\text { subjects with low intake of zinc still remain to be defined. }\end{array}$ \\
\hline Iron [71] & $\begin{array}{l}\text { Iron administered at high doses (i.e., iron-zinc ratio of 25:1 molar) reduce } \\
\text { zinc absorption. } \\
\text { Duration of iron supplementation does not affect zinc status }\end{array}$ \\
\hline Vitamin A [72] & $\begin{array}{l}\text { Severe vitamin A deficiency may reduce absorption and lymphatic } \\
\text { transport of zinc by altering synthesis of zinc-dependent protein }\end{array}$ \\
\hline Folic acid [73] & $\begin{array}{l}\text { Supplementation with folate may impair zinc absorption by insoluble } \\
\text { chelate formation }\end{array}$ \\
\hline
\end{tabular}

\section{Diagnosis of Zinc Deficiency in Preterm Neonate}

Accurate biomarkers of zinc status are still lacking. Measurement of serum zinc concentrations remains the best-albeit imperfect-marker to identify zinc deficiency (Table 5) [76-79]. Based on the data obtained from cord blood at birth, it is reasonable to identify a condition of zinc deficiency with serum concentrations at birth below $55 \mathrm{mcg} / \mathrm{dL}(8.4 \mathrm{mcmol} / \mathrm{L})$ [80]. Serum zinc levels measured in cord blood at birth are higher in preterm compared with at term neonates (Table 6) [81-86]. Figure 3 depicts serum levels of zinc in preterm neonates in the first 28 days of life [58-61]. In preterm neonates, serum zinc levels rapidly decline during the first month of life, so that, at post-conceptional age of 40 weeks, serum zinc concentrations may be lower in preterm neonates compared with term neonates [58-61].

Typical clinical manifestations are commonly observed only for conditions of severe zinc deficiency. Increasing data suggest significant subclinical effects of a moderate zinc deficiency in preterm neonate [87]. Thus, an increase in zinc supplementation should be considered in all neonates with reduced serum zinc concentrations. 
Table 5. Diagnostic tools for the diagnosis of zinc deficiency.

\begin{tabular}{|c|c|c|}
\hline $\begin{array}{l}\text { Biologic Samples Used for Zinc } \\
\text { Concentrations Measurement }\end{array}$ & Characteristics & Limitations on the Use in Preterm Neonate \\
\hline Serum or plasma [76] & $\begin{array}{l}\text { It is the only biochemical indicator recommended by WHO to } \\
\text { assess zinc status. } \\
\text { Levels vary according to zinc intakes } \\
\text { It may be used to predict response to zinc supplementation } \\
\text { It is readily available as an early marker of severe deficit }\end{array}$ & $\begin{array}{l}\text { Adventitious zinc can easily be added to samples by environmental } \\
\text { exposure and inappropriate sample handling } \\
\text { Zinc is released from hemolysed red blood cells into the serum. } \\
\text { Low specificity (serum zinc concentrations decrease with a number } \\
\text { of conditions such as infection, trauma, stress, steroid use, } \\
\text { metabolic redistribution of zinc from the plasma to the tissues, } \\
\text { concurrent nutrient deficiency). } \\
\text { Starvation can induce the release of zinc in the circulation. } \\
\text { The time of the day when blood samples are drawn has a } \\
\text { significant effect on serum zinc concentrations (serum zinc is higher } \\
\text { in morning samples than in afternoon or evening samples) }\end{array}$ \\
\hline $\begin{array}{l}\text { Intracellular concentrations } \\
\text { (erythrocytes, platelets, } \\
\text { leucocytes) }[76,77]\end{array}$ & $\begin{array}{l}\text { Provides information on zinc status over a longer time period } \\
\text { (independent of serum turn-over). }\end{array}$ & $\begin{array}{l}\text { Absence of standardization and reference values in neonates } \\
\text { Large volumes of blood required for the assay } \\
\text { Sophisticated technology useful to isolate cells }\end{array}$ \\
\hline Metalloenzymes [78] & Rapid response to zinc supplementation & No data on diagnostic accuracy in preterm neonates. \\
\hline Hair [79] & $\begin{array}{l}\text { Provides information on zinc status over a longer time period } \\
\text { Easy to collect }\end{array}$ & $\begin{array}{l}\text { Variability with age, sex, season, hair growth rate, and hair color } \\
\text { No standardized methods for collection, washing, and analysis of } \\
\text { hair samples in neonates }\end{array}$ \\
\hline
\end{tabular}


Table 6. Zinc levels in neonatal cord blood at birth by gestational age and birth weight.

\begin{tabular}{|c|c|c|c|c|}
\hline Reference & $\begin{array}{l}\text { Number of } \\
\text { Neonates }\end{array}$ & $\begin{array}{l}\text { Gestational Age } \\
\text { at Birth, Weeks }\end{array}$ & Birth Weight, g & $\begin{array}{c}\text { Mean Values } \pm \text { Standard } \\
\text { Deviation }(\mu \mathrm{g} / \mathrm{dL})\end{array}$ \\
\hline \multirow{3}{*}{$\begin{array}{c}\text { Jeswani et al., } \\
1991 \text { [81] }\end{array}$} & 25 & $<37$ & $1790 \pm 380$ & $94 \pm 18$ \\
\hline & 25 & $>37$ & $2800 \pm 200$ & $129 \pm 14$ \\
\hline & 10 & $>37$ & $1880 \pm 150$ & $112 \pm 9$ \\
\hline \multirow{7}{*}{$\begin{array}{l}\text { Wasowicz et al., } \\
1993 \text { [82] }\end{array}$} & 51 & $>37$ & & $81 \pm 24$ \\
\hline & 51 & $<37$ & & $93 \pm 12$ \\
\hline & 23 & & $1500-2499$ & $85 \pm 13$ \\
\hline & 41 & & $2500-4750$ & $81 \pm 27$ \\
\hline & 13 & $24-36$ & & $92 \pm 12$ \\
\hline & 15 & $37-38$ & & $87 \pm 33$ \\
\hline & 36 & $39-41$ & & $78 \pm 19$ \\
\hline \multirow{9}{*}{$\begin{array}{c}\text { Iqbal et al., } 2001 \\
{[83]}\end{array}$} & 3 & $28-33$ & & $90 \pm 47$ \\
\hline & 29 & $34-36$ & & $88 \pm 30$ \\
\hline & 22 & $37-39$ & & $83 \pm 39$ \\
\hline & 11 & $40-41$ & & $79 \pm 24$ \\
\hline & 11 & & 1000-1500 & $103 \pm 37$ \\
\hline & 16 & & $1600-2000$ & $81 \pm 25$ \\
\hline & 10 & & $2100-2500$ & $79 \pm 29$ \\
\hline & 18 & & $2600-3000$ & $83 \pm 43$ \\
\hline & 10 & & $3100-4000$ & $81 \pm 14$ \\
\hline \multirow{4}{*}{$\begin{array}{l}\text { Perveen et al., } \\
\quad 2002[84]\end{array}$} & 11 & $24-28$ & & $116 \pm 45$ \\
\hline & 11 & $29-33$ & & $94 \pm 19$ \\
\hline & 9 & $34-37$ & & $89 \pm 15$ \\
\hline & 11 & $38-42$ & & $87 \pm 9$ \\
\hline \multirow{5}{*}{$\begin{array}{l}\text { Galinier et al., } \\
\quad 2005 \text { [85] }\end{array}$} & 53 & $26-31$ & & $160 \pm 27$ \\
\hline & 76 & $31-33$ & & $137 \pm 30$ \\
\hline & 66 & $33-34$ & & $125 \pm 23$ \\
\hline & 53 & $34-37$ & & $128 \pm 18$ \\
\hline & 262 & $>37$ & $3234 \pm 358$ & $123 \pm 20$ \\
\hline \multirow{2}{*}{$\begin{array}{c}\text { Tsuzuki et al., } \\
2013 \text { [86] }\end{array}$} & 14 & $36 \pm 2$ & $2388 \pm 465$ & $89 \pm 14$ \\
\hline & 30 & $39 \pm 1$ & $3043 \pm 321$ & $86 \pm 16$ \\
\hline
\end{tabular}

\section{Zinc Deficiency and Neonatal Complications}

Typical signs of zinc deficiency in newborns include dermatitis and growth impairment $[88,89]$. However, the zinc status in the first weeks of life may influence the occurrence of many other pathological conditions interfering with their crucial pathogenic steps.

\subsection{Dermatitis}

Rash is the most common clinical feature of zinc deficiency, often misdiagnosed as Candida, eczema, or impetigo $[88,90]$. In preterm infants, the characteristic skin changes may occur early in the anterior neck fold, with poorly marginated erythema in the depth of the fold, that becomes well demarcated and scaled within five days $[80,88,90]$. Deficient patients respond quickly to oral zinc supplementation, usually within one week [91]. Many of the skin lesions observed in preterm neonates after the first week of life may depend on a zinc deficiency [51-92]. Thus, evaluation of zinc status is recommended in the newborn with dermatologic manifestation that cannot be explained otherwise.

\subsection{Growth Retardation}

Zinc intake has been associated with growth outcomes in both term and preterm infants over the first 12 months [51,93]. It seems clear that very preterm infants, who have poor zinc stores and great need for growth, are at particular risk of zinc deficiency, as shown by Ram Kumar et al. [94]. Itabashi et al. demonstrated an increased risk of low serum zinc levels with higher weight gain [95]. 
This phenomenon could be due to the increased enzyme activity and protein synthesis associated with growth. Zinc is a key element in the synthesis of proteins essential for growth [96]. Neonates with improved growth have greater zinc requirements and, consequently, present a higher risk of nutritional deficiency. However, this hypothesis remains, at present, still uninvestigated. On the other hand, zinc deficiency may limit neonatal growth; thus, its diagnosis should be considered for any preterm infant who is not growing well despite an apparently adequate energy and macronutrient intake, who has not consistently received a zinc-fortified human milk or formula designed for preterm infants, who has sustained any gastrointestinal resection or insult, or is on diuretic therapy $[50,51,97]$.

\subsection{Necrotizing Enterocolitis}

Necrotizing enterocolitis (NEC) is the most severe gastrointestinal emergency in neonates. In some intensive care units, NEC affects up to $10 \%$ of premature infants [98]. The pathogenic mechanisms of NEC are not yet completely understood. The combination of intestinal immaturity, hemodynamic instability, asphyxia, infections and impaired inflammatory response underlies the development of NEC [98]. Nutritional approach may significantly influence the risk of NEC [99]. Despite that the role of zinc in many intestinal functions and clinical conditions of children has been widely studied, the clinical effects of zinc on the neonatal intestine remain largely unexplored. Several experimental models and clinical evidences suggest a role for zinc in the pathogenesis of NEC $[87,100,101]$. Zinc modulates the expression of important inflammatory cytokines and their receptors in the intestine in models of colitis [102]. Subjects deficient in zinc showed a reduced immune response against pathogens [103]. Zinc also has trophic effects on intestinal mucosa and modulates intestinal permeability [104,105]. Finally, zinc deficiency worsens the extent of damage from asphyxiation due to the reduced enzymatic antioxidant activities [106]. However, no systematic study has been carried out so far on the possible role of zinc in the development of NEC. A multicenter trial on premature babies reported a significant reduction in NEC incidence in subjects receiving high doses of zinc [87]. Based on the above-mentioned evidence, it is reasonable to imagine a role for zinc in NEC prevention, and design specific studies in this field.

\subsection{Neurologic Damage}

Zinc regulates the expression of neurotrophic factors that reduce apoptosis subsequent to different types of insults and promote neuronal regeneration $[107,108]$. Very low birth weight babies (VLBW) are at high risk of hypoxic brain damage. Severity of brain damage is influenced by the activity of zinc-dependent metallothioneins [109]. In different models of hypoxia, brain lesions are directly correlated with zinc concentrations in experimental conditions [110]. Zinc seems essential also in the modulation of vascular tone at the cerebral level [111]. The reduced ability to control the tone of cerebral vessels is of critical importance in the development of hypoxic-ischemic injury and intraventricular hemorrhage in the preterm infant [108]. However, clinical trials on the role of zinc in the prevention of brain damage in preterm neonate are not available at the moment.

\subsection{Bronchopulmonary Dysplasia}

Despite significant improvement in neonatal care and the consequent reduction in mortality associated with respiratory complications, the incidence of bronchopulmonary dysplasia (BPD) has remained unchanged over the years [112]. In the last two decades, clinical presentation of BPD has varied significantly. New types of BPD, characterized by growth arrest of the respiratory tract or by destructive lesions, usually occur in extremely preterm infants (gestational age $<28$ weeks, birth weight $<750 \mathrm{~g}$ ), with little chance of survival until a few years ago [113]. In the new BPD, nutritional support is essential to promote the development of the respiratory tract and prevent further inflammatory damage deriving from mechanical ventilation and local or systemic infections [113]. For these reasons, prestigious scientific societies have recommended specific nutritional intakes for the prevention of bronchopulmonary dysplasia (BPD) [114]. The action of antioxidant enzymes is 
essential to reduce the oxidative damage induced by mechanical ventilation, and the remodeling action of metalloproteinase is essential in response to inflammatory damage [115]. Zinc promotes epithelial development, participates in the enzymatic reactions underlying the repair of tissue damage, protects against infection, and modulates the inflammatory response in the respiratory system [116]. Thus, it is reasonable to hypothesize a role of zinc in preventing bronchopulmonary dysplasia. However, clinical studies demonstrating a clear relationship between zinc and BPD are not yet available.

\subsection{Infections}

It has been clearly demonstrated that zinc deficiency increases risk and severity of infections by reducing immune response to pathogens [117]. Zinc is a crucial element of the immune response. The presence of zinc is essential to ensure the normal activity of enzymes, peptides and cytokines in the cells of immune system. This element stabilizes the membranes of immune cells by acting on the cytoskeleton and regulates apoptosis, diapedesis and recruitment of immune cells. A wealth of evidence and recent trials confirm the utility of zinc in the prevention and treatment of intestinal and extra intestinal infections $[117,118]$. However, there is still no data available on the effectiveness of zinc in preventing infectious diseases in preterm neonates.

\subsection{Retinopathy of Prematurity}

Retinopathy of prematurity (ROP) is a major cause of blindness worldwide [119]. ROP is induced by multiple pathogenic phases. Exposure to high oxygen concentrations induces the cessation of retinal vessel growth after premature birth, through the down-regulation of the expression of growth factors essential for adequate retinal development (i.e., Vascular endothelial growth factor: VEGF) [117]. The vascular depletion of the retina associated with body growth induces a state of chronic hypoxia and exposes the retina to the continuous risk of ischemia, especially in critically ill neonates [120]. Oxidative damage and inflammation, deriving from frequent ischemia-reperfusion injury, leads to an abnormal proliferation of vessels and pathologic neovascularization [119]. Zinc is the most abundant trace metal in the retina and may serve a critical function as antioxidant in this tissue [20]. Zinc also induces synthesis of metallothioneins, zinc-ion-binding proteins with a wide range of functions, including defense against oxidative damage and inflammation induced by hypoxia [120]. The human eye is enriched in metallothioneins. These zinc-enzymes contribute to antioxidant mechanisms of defense in the retina as in other ocular tissues [121]. It is possible to hypothesize a role of zinc in the inhibition of neovascularization, not only by reducing oxidative damage but also by controlling the expression of growth factors (i.e., VEGF). This issue may represent a fascinating field of research for future studies.

Despite these plausible assumptions, trials in neonates have failed to demonstrate the efficacy of antioxidants in preventing ROP. On the other hand, there is encouraging data from a trial on preterm neonates demonstrating a trend to a reduction in ROP in subjects receiving high doses of zinc [87].

\section{Supplementation of Zinc}

Preterm infants are generally believed to be in a negative zinc balance within the first 4- 8 weeks of life, unless intakes are not bolstered by specific supplements [122]. Zinc could be provided through parenteral nutrition support, or fortified human milk, formulas designed for premature infants, or specific products containing zinc. Zinc-supplemented parenteral nutrition early in postnatal life, followed by enteral administration of zinc in adequate doses, should aim to be sufficient to meet zinc requirements also for extremely low birth weight infants (ELBW). Several indications for zinc requirements are available (Table 7) [123-130]. Interestingly, recommended intakes have progressively increased during the last decade. The recommended enteral intake ranges between 0.8 to $3 \mathrm{mg} / \mathrm{Kg} /$ day [3]. Zinc requirements for term infants are estimated to be $0.8 \mathrm{mg} /$ day, whereas preterm neonates may require up to $3 \mathrm{mg} / \mathrm{kg}$ per day to achieve adequate zinc retention [3]. Less 
variability regarding intravenous supplementation may be found in the recommendations of different scientific societies and committees. Despite that only $60 \%$ of parenterally infused zinc is retained, different authors suggest parenteral supplementation with $350 \mathrm{mcg} / \mathrm{kg}$ per day [51,131]. Recent evidence supports the use of higher zinc doses to improve survival and reduce morbidity in VLBW neonates [87]. Higher zinc supplementation is also justified if we consider that in the last trimester of pregnancy the fetus receives up to $1 \mathrm{mg} / \mathrm{Kg} /$ day of zinc from the mother. Thus, to reach a similar intake, $0.5-0.8 \mathrm{mg} / \mathrm{Kg} /$ day or $4-5 \mathrm{mg} / \mathrm{Kg} /$ day zinc should be administered by the parenteral or oral route, respectively (Figure 4) [132,133]. However, further trials, including pharmacokinetic studies, are advocated before modifying current recommendations on the use of zinc.

Zinc requirement in preterm neonates is quite similar to that of fetuses with similar postconceptional age. However, a lower percentage of zinc administered in preterm neonates by enteral or parenteral nutrition is retained. Thus, if zinc is provided according to current recommendation (columns zinc intake), the final balance of zinc is negative, at variance with what happens during fetal life, when zinc is transferred by the placenta, directly in the fetal circulation, at a daily amount of about $900 \mathrm{mcg}$.

Table 7. Recommendations for zinc in neonates by enteral or parenteral route.

\begin{tabular}{|c|c|c|c|}
\hline $\begin{array}{l}\text { Institute/Scientific } \\
\text { Societies/Academic Groups }\end{array}$ & $\begin{array}{l}\text { Publication } \\
\text { Year }\end{array}$ & $\begin{array}{l}\text { Population of } \\
\text { Neonates }\end{array}$ & Dose (mg/Kg/Day) \\
\hline \multicolumn{4}{|l|}{ Enteral route } \\
\hline $\begin{array}{l}\text { The American Academy of Pediatrics } \\
\text { Committee on nutrition [123] }\end{array}$ & 1985 & All & 0.6 \\
\hline $\begin{array}{l}\text { Committee on Nutrition of the Preterm } \\
\text { Infant, European Society of Paediatric } \\
\text { Gastroenterology and Nutrition [124] }\end{array}$ & 1987 & All & $0.7-1.4$ \\
\hline Zlotkin et al. [125] & 1996 & $\begin{array}{l}0-14 \text { days of life } \\
>14 \text { day of life }\end{array}$ & $\begin{array}{c}0.5-0.8 \\
1\end{array}$ \\
\hline Klein et al. [126] & 2002 & $\begin{array}{l}\text { Birth weight }<1 \mathrm{Kg} \\
\text { Birth weight } 1-2 \mathrm{Kg} \\
\text { Birth weight }>2 \mathrm{Kg}\end{array}$ & $\begin{array}{c}2 \\
1.7 \\
1.3\end{array}$ \\
\hline Hambidge et al. [127] & 2006 & $\begin{array}{l}\text { Birth weight }<1 \mathrm{Kg} \\
\text { Birth weight } 1-2 \mathrm{Kg} \\
\text { Birth weight } 2-3.5 \mathrm{Kg}\end{array}$ & $\begin{array}{c}2.4 \\
2 \\
1.6\end{array}$ \\
\hline ESPGHAN Committee on Nutrition [128] & 2010 & Birth weight $<1.8 \mathrm{Kg}$ & $1.1-2.0$ \\
\hline Griffin et al. [129] & 2013 & $\begin{array}{l}\text { Human milk feed } \\
\text { Formula feed }\end{array}$ & $\begin{array}{l}2.3-2.4 \\
1.8-2.4\end{array}$ \\
\hline Parenteral route & & & \\
\hline American Society of Clinical Nutrition [130] & 1988 & All & 0.4 \\
\hline Zlotkin et al. [125] & 1996 & $\begin{array}{c}\text { Transitional period } \\
\text { Stable period }\end{array}$ & $\begin{array}{c}0.15 \\
0.4\end{array}$ \\
\hline
\end{tabular}




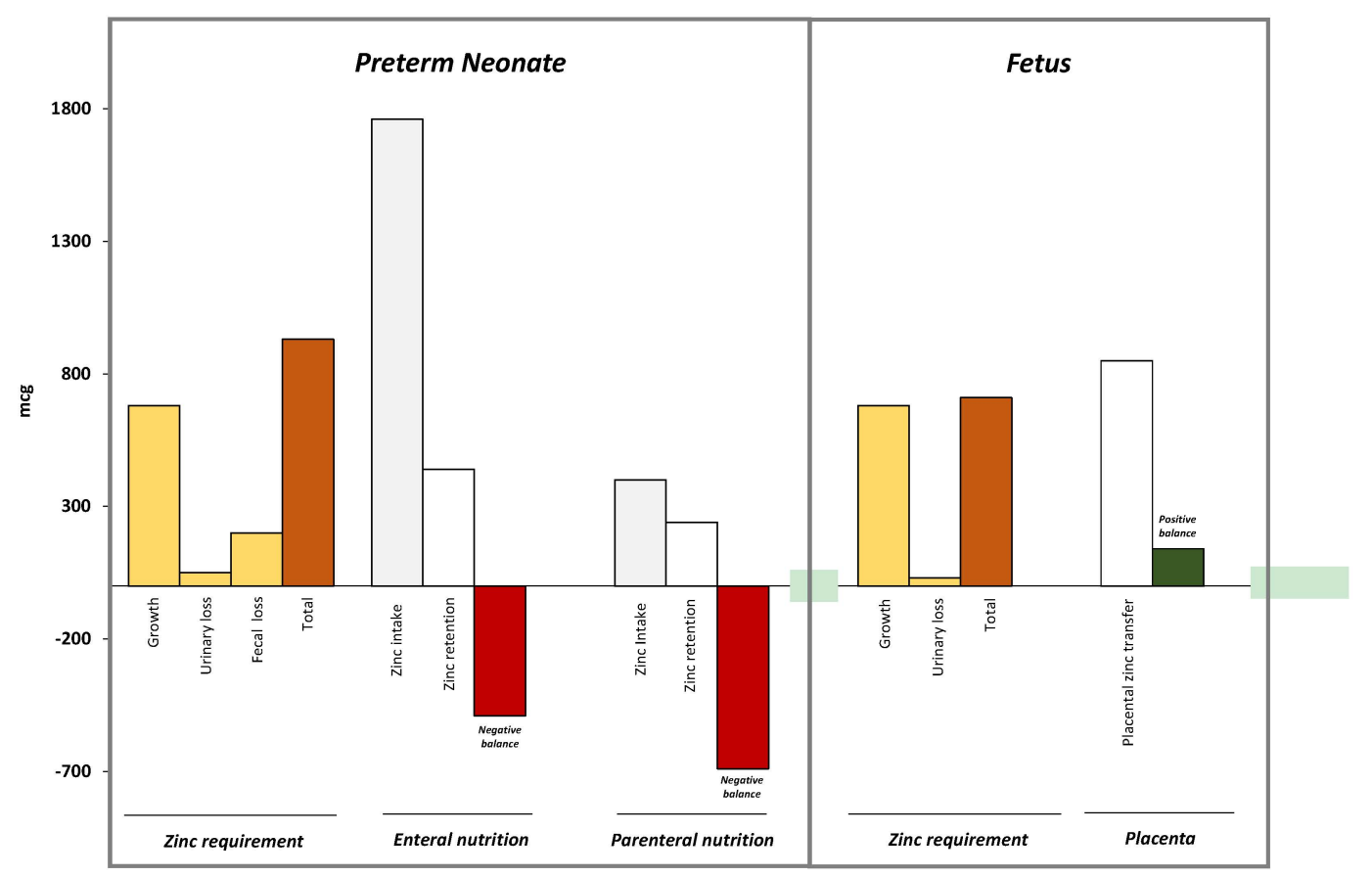

Figure 4. Zinc balance in fetal and neonatal life [132,133].

\section{Excessive Exposure to Zinc}

Zinc supplementation is generally safe. However, an excess of zinc ( $>20 \mathrm{mg} / \mathrm{Kg} /$ day) may influence absorption and retention of other trace elements such as copper and vitamin A [50,74]. Zinc may induce copper deficiency by inhibiting the gastrointestinal absorption [134]. On the other hand, copper supplementation boosts the conjugation of zinc with large molecules and depletes the ratio of zinc coupled with smaller molecules, thereby suggesting an antagonism between the transport of these two elements [135]. Indeed, no cases of hypocupremia have been described in trials using zinc in neonates (with doses ranging from 2 to $10 \mathrm{mg} / \mathrm{Kg} /$ day) not even when copper was not supplemented.

Zinc status influences vitamin A absorption, transport and utilization [74]. Evidence of an effect of zinc intake on vitamin A status from animal experiments are inconclusive, mainly because of the use of inadequate control groups [136]. Randomized trials in children have failed to show a consistent effect of zinc supplementation on vitamin A status [137] and there is no such evidence in neonates. To the best of our knowledge, none of the other potential consequences of zinc excess, such as cytopenias or myeloneuropathy, has been reported in neonates.

\section{Conclusions}

Zinc plays a crucial role during the first phase of life, including embryogenesis and fetal life. Preterm neonates continue their "fetal" development in an extra-uterine environment. Consequently, zinc stores are not completed and its requirement increase in babies born prematurely. Considering the large number of roles played by zinc in early life, the consequences of zinc deficiency in preterm neonates are extremely variable and may be severe in many cases. A large percentage of preterm neonates is affected by mild to moderate subclinical zinc deficiency. Diagnosis of zinc deficiency, especially if of mild severity, is not easy due to its nonspecific features and to the lack of highly sensitive biomarkers. On the other hand, early diagnosis may be essential to avoid severe consequences of zinc deficiency. Clinical evaluation and research of the risk factors associated with the measurement of serum level of zinc is the most appropriate approach in the diagnosis of zinc deficiency. Dealing with the deficiency by zinc supplements is highly effective in neonates, with 
proven benefits on skin lesions and growth. Supplementation with adequate doses of zinc may also reduce the occurrence and severity of the morbidities typical of prematurity. However, current recommendations for zinc seem inadequate to meet the requirement of extremely preterm neonates and should be revised.

Despite the consistent number of articles on the role of zinc in early life, many interesting aspects remain to be clarified. Possible area of future research may be summarized in ten issues:

1. Study of the role of zinc in infertility and multiple abortions

2. Identification of diet and environmental determinants of zinc absorption in otherwise well-nourished pregnant women

3. Evaluation of zinc metabolism in neonates with alcoholic syndrome

4. Definition of determinants of zinc absorption in preterm neonates

5. Calculation of diagnostic power of zinc concentration assessment in cells and hairs, and of metalloenzyme in preterm neonates

6. Definition of modalities for zinc supplementation in preterm neonates (doses, administration route, duration of therapy)

7. Evaluation of the usefulness of individualized zinc supplementation in human milk feeding for preterm neonates

8. Study of the relation between zinc and vitamin A in preterm neonates

9. Study of the relation between zinc deficiency and occurrence of morbidities (i.e., NEC, brain damage, BPD, infectious diseases, ROP) in preterm neonates.

10. Determination of zinc efficacy in reducing severe complications of prematurity and the study of the related mechanisms

When such data become available, the role of zinc in early life will be further clarified and the use of zinc in neonates could be optimized. Considering the critical role of zinc in neonatal life, research in this field is widely advocated.

Author Contributions: G.T., R.B.C. and M.De.C. wrote the first draft of the manuscript, to which M.Di.C., A.P. and F.C. contributed. G.T., M.Di.C., A.P., F.C. and V.A. revised with evidence available in the literature. All authors contributed to the final draft of the manuscript.

Conflicts of Interest: The authors declare no conflict of interest.

\section{References}

1. King, J.C. Zinc: An Essential but Elusive Nutrient. Am. J. Clin. Nutr. 2011, 94, 679S-684S. [CrossRef] [PubMed]

2. Vallee, B.L.; Auld, D.S. Zinc Coordination, Function, and Structure of Zinc Enzymes and Other Proteins. Biochemistry 1990, 19, 5647-5659. [CrossRef]

3. Hambidge, K.M.; Krebs, N.F. Zinc in the Fetus and Neonate. In Fetal Neonatal Physiol; Elsevier Saunders: Philadelphia, PA, USA, 2004; pp. 342-347.

4. Vallee, B.L.; Auld, D.S. Active Zinc Binding Sites of Zinc Metalloenzymes. Matrix Suppl. 1992, 1, 5-19. [PubMed]

5. Palmiter, R.D. The Elusive Function of Metallothioneins. Proc. Natl. Acad. Sci. USA 1998, 21, 8428-8430. [CrossRef]

6. Hijova, E. Metallothioneins and zinc: Their functions and interactions. Bratisl. Lek. Listy 2004, 105, 230-234. [PubMed]

7. Hanas, J.S.; Hazuda, D.J.; Bogenhagen, D.F.; Wu, F.Y.; Wu, C.W. Xenopus Transcription factor a requires zinc for binding to the 5 S RNA gene. J. Biol. Chem. 1983, 10, 14120-14125.

8. Miller, J.; McLachlan, A.D.; Klug, A. Repetitive zinc-binding domains in the protein transcription factor IIIA from Xenopus oocytes. EMBO J. 1985, 4, 1609-1614. [PubMed]

9. Shang, Z.; Liao, Y.D.; Wu, F.Y.; Wu, C.W. Zinc Release from Xenopus transcription factor IIIA induced by chemical modifications. Biochemistry 1989, 12, 9790-9795. [CrossRef] 
10. Evans, R.M. The steroid and thyroid hormone receptor superfamily. Science 1988, 13, 889-895. [CrossRef]

11. Fukada, T.; Yamasaki, S.; Nishida, K.; Murakami, M.; Hirano, T. Zinc homeostasis and signaling in health and diseases: Zinc signaling. J. Biol. Inorg. Chem. 2011, 16, 1123-1134. [CrossRef] [PubMed]

12. Prasad, A.S. Zinc in human health: Effect of zinc on immune cells. Mol. Med. 2008, 14, 353-357. [CrossRef] [PubMed]

13. Prasad, A.S.; Meftah, S.; Abdallah, J.; Kaplan, J.; Brewer, G.J.; Bach, J.F.; Dardenne, M. Serum thymulin in human zinc deficiency. J. Clin. Investig. 1988, 82, 1202-1210. [CrossRef] [PubMed]

14. Summersgill, H.; England, H.; Lopez-Castejon, G.; Lawrence, C.B.; Luheshi, N.M.; Pahle, J.; Mendes, P.; Brough, D. Zinc depletion regulates the processing and secretion of IL-1 $\beta$. Cell Death Dis. 2014, 30, e1040. [CrossRef] [PubMed]

15. Grahn, B.H.; Paterson, P.G.; Gottschall-Pass, K.T.; Zhang, Z. Zinc and the eye. J. Am. Coll. Nutr. 2001, 20, 106-118. [CrossRef] [PubMed]

16. MacDonald, R.S. The Role of Zinc in Growth and Cell Proliferation. J. Nutr. 2000, 130, 1500S-1508S. [PubMed]

17. Bobat, R.; Coovadia, H.; Stephen, C.; Naidoo, K.L.; McKerrow, N.; Black, R.E.; Moss, W.J. Safety and Efficacy of Zinc Supplementation for Children with HIV-1 Infection in South Africa: A randomised double-blind placebo-controlled trial. Lancet 2005, 366, 1862-1867. [CrossRef]

18. Wastney, M.E.; Angelus, P.A.; Barnes, R.M.; Subramanian, K.N. Zinc absorption, distribution, excretion, and retention by healthy preterm infants. Pediatr. Res. 1999, 45, 191. [CrossRef] [PubMed]

19. Zlotkin, S.H.; Cherian, M.G. Hepatic Metallothionein as a Source of Zinc and Cysteine during the First Year of Life. Pediatr. Res. 1988, 24, 326-329. [CrossRef] [PubMed]

20. Falchuk, K.H. The Molecular Basis for the Role of Zinc in Developmental Biology. Mol. Cell Biochem. 1998, 188, 41-48. [CrossRef] [PubMed]

21. Record, I.R. Zinc Deficiency and the Developing Embryo. Neurotoxicology 1987, 8, 369-378. [PubMed]

22. Simmer, K.; Lort-Phillips, L.; James, C.; Thompson, R.P. A Double-blind Trial of Zinc Supplementation in Pregnancy. Eur. J. Clin. Nutr. 1991, 45, 139-144. [PubMed]

23. Hambidge, K.M.; Hackshaw, A. Neural Tube Defects and Serum Zinc. Br. J. Obstet. Gynaecol. 1993, 100, 746-749. [CrossRef] [PubMed]

24. Keen, C.L.; Hurley, L.S.; Lönnerdal, B. Effects of Zinc Deficiency on Prenatal and Postnatal Development. Fed. Proc. 1987, 42, 1735-1739.

25. Hurley, L.S. Zinc Deficiency in the Developing Rats. Am. J. Clin. Nutr. 1969, 22, 1332-1339. [PubMed]

26. Hickory, W.; Nanda, R.; Catalanotto, F.A. Fetal Skeletal Malformations Associated with Moderate Zinc Deficiency during Pregnancy. J. Nutr. 1979, 109, 883-891. [PubMed]

27. Rogers, J.M.; Keen, C.L.; Hurley, L.S. Zinc Deficiency in Pregnant Long-Evans Hooded Rats: Teratogenicity and Tissue Trace Elements. Teratology 1985, 31, 89-100. [CrossRef] [PubMed]

28. Falchuk, K.H.; Montorzi, M. Zinc Physiology and Biochemistry in Oocytes and Embryos. Biometals 2001, 14, 385-395. [CrossRef] [PubMed]

29. Velie, E.M.; Block, G.; Shaw, G.M.; Samuels, S.J.; Schaffer, D.M.; Kulldorff, M. Maternal Supplemental and Dietary Zinc and the Occurrence of Neural Tube Defects in California. Am. J. Epidemiol. 1999, 150, 605-616. [CrossRef] [PubMed]

30. Cengiz, B.; Söylemez, F.; Oztürk, E.; Cavdar, A.O. Serum Zinc, Selenium, Copper, and Lead Levels in Women with Second-Trimester Induced Abortion Resulting from Neural Tube Defects: A Preliminary Study. Biol. Trace Elem. Res. 2004, 97, 225-235. [CrossRef]

31. Zeyrek, D.; Soran, M.; Cakmak, A.; Kocyigit, A.; Iscan, A. Serum Copper and Zinc Levels in Mothers and Cord Blood of Their Newborn Infants with Neural Tube Defects: A Case-control Study. Indian Pediatr. 2009, 46, 675-680. [PubMed]

32. Dey, A.C.; Shahidullah, M.; Mannan, M.A.; Noor, M.K.; Saha, L.; Rahman, S.A. Maternal and Neonatal Serum Zinc Level and its Relationship with Neural Tube Defects. J. Health Popul. Nutr. 2010, 28, 343-350. [CrossRef] [PubMed]

33. Masters, D.G.; Keen, C.L.; Lönnerdal, B.; Hurley, L.S. Zinc deficiency teratogenicity: The protective role of maternal tissue catabolism. J. Nutr. 1983, 113, 905-912. [PubMed]

34. Miller, S.I.; del Villano, B.C.; Flynn, A.; Krumhansl, M. Interaction of alcohol and zinc in fetal dysmorphogenesis. Pharmacol. Biochem. Behav. 1983, 18, 311-315. [CrossRef] 
35. Zidenberg-Cherr, S.; Rosenbaum, J.; Keen, C.L. Influence of ethanol consumption on maternal-fetal transfer of zinc in pregnant rats on day 14 of pregnancy. J. Nutr. 1988, 118, 865-870. [PubMed]

36. Da Cunha Ferreira, R.M.; Marquiegui, I.M.; Elizaga, I.V. Teratogenicity of zinc deficiency in the rat: Study of the fetal skeleton. Teratology 1989, 39, 181-194. [CrossRef] [PubMed]

37. Keen, C.L.; Uriu-Adams, J.Y.; Skalny, A.; Grabeklis, A.; Grabeklis, S.; Green, K.; Yevtushok, L.; Wertelecki, W.W.; Chambers, C.D. The Plausibility of Maternal Nutritional Status Being a Contributing Factor to the Risk for Fetal Alcohol Spectrum Disorders the Potential Influence of Zinc Status as an Example. Biofactors 2010, 36, 125-135. [CrossRef] [PubMed]

38. Keppen, L.D.; Pysher, T.; Rennert, O.M. Zinc Deficiency Acts as a Co-teratogen with Alcohol in Fetal Alcohol Syndrome. Pediatr. Res. 1985, 19, 944-947. [CrossRef] [PubMed]

39. McClain, C.J.; Kasarskis, E.J., Jr.; Allen, J.J. Functional Consequences of Zinc Deficiency. Prog. Food Nutr. Sci. 1985, 9, 185-226. [PubMed]

40. Wastney, M.E.; Angelus, P.; Barnes, R.M.; Subramanian, K.N. Zinc Kinetics in Preterm Infants: A Compartmental Model Based on Stable Isotope Data. Am. J. Physiol. 1996, 271, 1452-1459.

41. Donangelo, C.M.; King, J.C. Maternal Zinc Intakes and Homeostatic Adjustments during Pregnancy and Lactation. Nutrients 2012, 4, 782-798. [CrossRef] [PubMed]

42. Bax, C.M.; Bloxam, D.L. Two Major Pathways of Zinc (II) Acquisition by Human Placental Syncytiotrophoblast. J. Cell. Physiol. 1995, 164, 546-554. [CrossRef] [PubMed]

43. Ota, E.; Mori, R.; Middleton, P.; Tobe-Gai, R.; Mahomed, K.; Miyazaki, C.; Bhutta, Z.A. Zinc supplementation for improving pregnancy and infant outcome. Cochrane Database Syst. Rev. 2015, 2, 10.

44. Goldenberg, R.L.; Tamura, T.; Neggers, Y.; Copper, R.L.; Johnston, K.E.; DuBard, M.B.; Hauth, J.C. The Effect of Zinc Supplementation on Pregnancy Outcome. JAMA 1995, 9, 463-468. [CrossRef]

45. King, J.C. Determinants of Maternal Zinc Status during Pregnancy. Am. J. Clin. Nutr. 2000, 71, 1334S-1343S. [PubMed]

46. Sandstead, H.H.; Freeland-Graves, J.H. Dietary Phytate, Zinc and Hidden Zinc Deficiency. J. Trace Elem. Med. Biol. 2014, 28, 414-417. [CrossRef] [PubMed]

47. Hambidge, K.M.; Miller, L.V.; Westcott, J.E.; Krebs, N.F. Dietary Reference Intakes for Zinc may Require Adjustment for Phytate Intake Based upon Model Predictions. J. Nutr. 2008, 138, 2363-2366. [CrossRef] [PubMed]

48. Sur, D.; Gupta, D.N.; Mondal, S.K.; Ghosh, S.; Manna, B.; Rajendran, K.; Bhattacharya, S.K. Impact of Zinc Supplementation on Dhiarroeal Morbidity and Growth Pattern of Low Birth Weight Infants in Kolkata India: A randomized, double-blind, placebo-controlled, community-based study. Pediatrics 2003, 112, 1327-1332. [CrossRef] [PubMed]

49. Wulf, K.; Wilhelm, A.; Spielmann, M.; Wirth, S.; Jenke, A.C. Frequency of Symptomatic Zinc Deficiency in very Low Birth Weight Infants. Klin. Padiatr. 2013, 225, 13-17. [CrossRef] [PubMed]

50. Hemalatha, P.; Bhaskaram, P.; Kumar, P.A.; Khan, M.M.; Islam, M.A. Zinc Status of Breastfed and Formula-fed Infants of Different Gestational Ages. J. Trop. Pediatr. 1997, 43, 52-54. [CrossRef] [PubMed]

51. Giles, E.; Doyle, L.W. Zinc in extremely Low-Birthweight or Very Preterm Infants. Neoreviews 2007, 8, e165-e172. [CrossRef]

52. Picciano, M.F.; Guthrie, H.A. Copper, Iron, and Zinc Contents of Mature Human Milk. Am. J. Clin. Nutr. 1976, 29, 242-254. [PubMed]

53. Walravens, P.A.; Chakar, A.; Mokni, R.; Denise, J.; Lemonnier, D. Zinc supplements in breastfed infants. Lancet 1992, 9, 683-685. [CrossRef]

54. Castillo-Durán, C.; Rodríguez, A.; Venegas, G.; Alvarez, P.; Icaza, G. Zinc supplementation and growth of infants born small for gestational age. J. Pediatr. 1995, 127, 206-211. [CrossRef]

55. Ehrenkranz, R.A.; Gettner, P.A.; Nelli, C.M.; Sherwonit, E.A.; Williams, J.E.; Ting, B.T.; Janghorbani, M. Zinc and Copper Nutritional Studies in very Low Birth Weight Infants: Comparison of stable isotopic extrinsic tag and chemical balance. Pediatr. Res. 1989, 26, 298-307. [CrossRef] [PubMed]

56. Passariello, A.; Terrin, G.; Baldassarre, M.E.; de Curtis, M.; Paludetto, R.; Berni Canani, R. Diarrhea in neonatal intensive care unit. World J. Gastroenterol. 2010, 7, 2664-2668. [CrossRef]

57. Dauncey, M.J.; Shaw, J.C.; Urman, J. The Absorption and Retention of Magnesium, Zinc and Copper by Low Birth Weight Infants Fed Pasteurized Human Breast Milk. Pediatr. Res. 1977, 11, 1033-1039. [CrossRef] [PubMed] 
58. Shaw, J.C. Trace elements in the Fetus and Young Infant. I. Zinc. Am. J. Dis. Child. 1979, 133, 1260-1268. [CrossRef] [PubMed]

59. Gibson, R.S.; Dewolfe, M.S. Changes in Serum Zinc Concentrations of Some Canadian Full Term and Low Birthweight Infants from Birth to Six Months. Acta Paedtr. 1981, 70, 497-500. [CrossRef]

60. Tyrala, E.E.; Manser, J.I.; Brodsky, N.L.; Tran, N. Serum Zinc Concentrations in Growing Premature Infants. Acta Paediatr. Scand. 1983, 72, 695-698. [CrossRef] [PubMed]

61. McMaster, D.; Lappin, T.R.; Halliday, H.L.; Patterson, C.C. Serum Copper and Zinc Levels in the Preterm Infant. A longitudinal Study of the First Year of Life. Biol. Neonate. 1983, 44, 108-113. [CrossRef] [PubMed]

62. Kelleher, S.L.; Lönnerdal, B. Zinc transporters in the rat mammary gland respond to marginal zinc and vitamin A intakes during lactation. J. Nutr. 2002, 132, 3280-3285. [PubMed]

63. Kumar, L.; Michalczyk, A.; McKay, J.; Ford, D.; Kambe, T.; Hudek, L.; Varigios, G.; Taylor, P.E.; Ackland, M.L. Altered Expression of Two Zinc Transporters, SLC30A5 and SLC30A6underlies a Mammary Gland Disorder of Reduced Zinc Secretion into Milk. Genes Nutr. 2015, 10, 38. [CrossRef] [PubMed]

64. Sandström, B.; Cederblad, A. Zinc Absorption from Composite Meals. II. Influence of the main protein source. Am. J. Clin. Nutr. 1980, 33, 1778-1783. [PubMed]

65. Snedeker, S.M.; Greger, J.L. Metabolism of Zinc, Copper and Iron as affected by Dietary Protein, Cysteine and histidine. J. Nutr. 1983, 113, 644-652. [PubMed]

66. Sandström, B.; Almgren, A.; Kivistö, B.; Cederblad, A. Effect of Protein Level and Protein Source on Zinc Absorption in Humans. J. Nutr. 1989, 119, 48-53. [PubMed]

67. Hurrell, R.F.; Lynch, S.R.; Trinidad, T.P.; Dassenko, S.A.; Cook, J.D. Iron Absorption in Humans as Influenced by Bovine Milk Proteins. Am. J. Clin. Nutr. 1989, 49, 546-552. [PubMed]

68. Sandström, B.; Sandberg, A.S. Inhibitory Effects of Isolated Inositol Phosphates on Zinc Absorption in Humans. J. Trace Elem. Electrolytes Health. Dis. 1992, 6, 99-103. [PubMed]

69. Voyer, M.; Davakis, M.; Antener, I.; Valleur, D. Zinc Balances in Preterm Infants. Biol. Neonate 1982, 42, 87-92. [CrossRef] [PubMed]

70. August, D.; Janghorbani, M.; Young, V.R. Determination of Zinc and Copper Absorption at Three Dietary Zn-Cu by Using Stable Isotope Methods in Young Adult and Elderly Subjects. Am. J. Clin. Nutr. 1989, 50, 1457-1463. [PubMed]

71. Sandström, B.; Davidsson, L.; Cederblad, A.; Lönnerdal, B. Oral iron, Dietary Ligands and Zinc Absorption. J. Nutr. 1985, 115, 411-414. [PubMed]

72. Christian, P.; Shahid, F.; Rizvi, A.; Klemm, R.D.; Bhutta, Z.A. Treatment Response to Standard of Care for Severe Anemia in Pregnant Women and Effect of Multivitamins and Enhanced Anthelminthics. Am. J. Clin. Nutr. 2009, 89, 853-861. [CrossRef] [PubMed]

73. Milne, D.B.; Canfield, W.K.; Mahalko, J.R.; Sandstead, H.H. Effect of Oral Folic Acid Supplements on Zinc, Copper, and Iron Absorption and Excretion. Am. J. Clin. Nutr. 1984, 39, 535-539. [PubMed]

74. Smith, J.C., Jr.; Brown, E.D.; McDaniel, E.G.; Chan, W. Alterations in Vitamin A Metabolism during Zinc Deficiency and Food and Growth Restriction. J. Nutr. 1976, 106, 569-574. [PubMed]

75. Christian, P.; West, K.P., Jr. Interactions between Zinc and Vitamin A: An update. Am. J. Clin. Nutr. 1998, 68, 435S-441S. [PubMed]

76. Gibson, R.S.; Hess, S.Y.; Hotz, C.; Brown, K.H. Indicators of Zinc Status at the Population Level: A review of the evidence. Br. J. Nutr. 2008, 99, S14-23. [CrossRef] [PubMed]

77. Thompson, R.P. Assessment of Zinc Status. Proc. Nutr. Soc. 1991, 50, 19-28. [CrossRef] [PubMed]

78. King, J.C. Assessment of Zinc Status. J. Nutr. 1990, 120, 1474-1479. [PubMed]

79. Hambidge, K.M. Hair Analyses: Worthless for vitamins, limited for minerals. Am. J. Clin. Nutr. 1982, 36, 943-949. [PubMed]

80. Hambidge, K. Copper. In Neonatal Nutrition and Metabolism, 2nd ed.; Thureen, P., Hay, W., Jr., Eds.; Cambridge University Press: Cambridge, UK, 2006; pp. 281-292.

81. Jeswani, R.M.; Vani, S.N. A study of Serum Zinc Levels in Cord Blood of Neonates and their Mothers. Indian J. Pediatr. 1991, 58, 683-686. [CrossRef] [PubMed]

82. Wasowicz, W.; Wolkanin, P.; Bednarski, M.; Gromadzinska, J.; Sklodowska, M.; Grzybowska, K. Plasma trace element (Se, $\mathrm{Zn}, \mathrm{Cu}$ ) concentrations in maternal and umbilical cord blood in Poland. Relation with birth weight, gestational age, and parity. Biol. Trace Elem. Res. 1993, 38, 205-215. [CrossRef] [PubMed] 
83. Iqbal, A.S.; Shahidullah, M.; Islam, M.N.; Akhter, S.; Banu, S. Serum Zinc and Copper Levels in the Maternal Blood and Cord Blood of Neonates. Indian J. Pediatr. 2001, 68, 523-526. [CrossRef] [PubMed]

84. Perveen, S.; Altaf, W.; Vohra, N.; Bautista, M.L.; Harper, R.G.; Wapnir, R.A. Effect of Gestational Age on Cord Blood Plasma Copper, Zinc, Magnesium and Albumin. Early Hum. Dev. 2002, 69, 15-23. [CrossRef]

85. Galinier, A.; Périquet, B.; Lambert, W.; Garcia, J.; Assouline, C.; Rolland, M.; Thouvenot, J.P. Reference Range for Micronutrients and Nutritional Marker Proteins in Cord Blood of Neonates Appropriated for Gestational Ages. Early Hum. Dev. 2005, 81, 583-593. [CrossRef] [PubMed]

86. Tsuzuki, S.; Morimoto, N.; Hosokawa, S.; Matsushita, T. Associations of Maternal and Neonatal Serum Trace Element Concentrations with Neonatal Birth Weight. PLOS ONE 2013, 27, e75627. [CrossRef] [PubMed]

87. Terrin, G.; Berni Canani, R.; Passariello, A.; Messina, F.; Conti, M.G.; Caoci, S.; Smaldore, A.; Bertino, E.; de Curtis, M. Zinc supplementation reduces morbidity and mortality in very-low-birth-weight preterm neonates: A hospital-based randomized, placebo-controlled trial in an industrialized country. Am. J. Clin. Nutr. 2013, 98, 1468-1474. [CrossRef] [PubMed]

88. Arlette, J.P.; Johnston, M.M. Zinc Deficiency Dermatosis in Premature Infants Receiving Prolonged Parenteral Alimentation. J. Am. Acad. Dermatol. 1981, 5, 37-42. [CrossRef]

89. Islam, M.N.; Chowdhury, A.K.; Siddika, M.; Hossain, M.A.; Hossain, M.K. Effect of Zinc on Growth of Preterm Babies. Mymensingh Med. J. 2009, 18, 125-130. [PubMed]

90. Prasad, A.S. Zinc Deficiency in Human Subjects. Prog. Clin. Biol. Res. 1983, 129, 1-33. [PubMed]

91. Zattra, E.; Belloni Fortina, A. Transient Symptomatic Zinc Deficiency Resembling Acrodermatitis Enteropathica in a Breast-fed Premature Infant: Case report and brief review of the literature. G. Ital. Dermatol. Venereol. 2013, 148, 699-702. [PubMed]

92. Perafán-Riveros, C.; França, L.F.; Alves, A.C.; Sanches, J.A., Jr. Acrodermatitis Enteropathica: Case report and review of the literature. Pediatr. Dermatol. 2002, 19, 426-431. [CrossRef] [PubMed]

93. Islam, M.N.; Chowdhury, M.A.; Siddika, M.; Qurishi, S.B.; Bhuiyan, M.K.; Hoque, M.M.; Akhter, S. Effect of Oral Zinc Supplementation on the Growth of Preterm Infants. Indian Pediatr. 2010, 47, 845-849. [CrossRef] [PubMed]

94. Ram Kumar, T.V.; Ramji, S. Effect of Zinc Supplementation on Growth in very Low Birth Weight Infants. J. Trop. Pediatr. 2012, 58, 50-54. [CrossRef] [PubMed]

95. Itabashi, K.; Saito, T.; Ogawa, Y.; Uetani, Y. Incidence and Predicting Factors of Hypozincemia in very-low-birth-weight Infants at Near-term Postmenstrual Age. Biol. Neonate 2003, 83, 235-240. [CrossRef] [PubMed]

96. Golden, B.E.; Golden, M.H. Effect of Zinc on Lean Tissue Synthesis during Recovery from Malnutrition. Eur. J. Clin. Nutr. 1992, 46, 697-706. [PubMed]

97. Laureano, A.; Brás, S.; Carvalho, R.; Amaro, C.; Cardoso, J. Transient Symptomatic Zinc Deficiency in a Preterm Exclusively Breast-fed Infant. Dermatol. Online J. 2014, 20, 14.

98. Terrin, G.; Scipione, A.; de Curtis, M. Update in Pathogenesis and Prospective in Treatment of Necrotizing Enterocolitis. Biomed. Res. 2014, 2014, 543765. [CrossRef] [PubMed]

99. Terrin, G.; Passariello, A.; Canani, R.B.; Manguso, F.; Paludetto, R.; Cascioli, C. Minimal enteral feeding reduces the risk of sepsis in feed-intolerant very low birth weight newborns. Acta Pediatr. 2009, 98, 31-35. [CrossRef] [PubMed]

100. Harper, J.I.; Thompson, D.; Kovar, I.Z.; Copeman, P.W.; Barltrop, D. Zinc Deficiency in a Preterm Neonate with Necrotizing Enterocolitis. J. R. Soc. Med. 1984, 77, 40-41. [PubMed]

101. Suwendi, E.; Iwaya, H.; Lee, J.S.; Hara, H.; Ishizuka, S. Zinc Deficiency Induces Dysregulation of Cytokine Productions in an Experimental Colitis of Rats. Biomed. Res. 2012, 33, 329-336. [CrossRef] [PubMed]

102. De Queiroz, C.A.; Fonseca, S.G.; Frota, P.B.; Figueiredo, I.L.; Aragão, K.S.; Magalhães CEde Carvalho, C.B.; Lima, A.Â.; Ribeiro, R.A.; Guerrant, R.L.; Moore, S.R.; et al. Zinc Treatment Ameliorates Diarrhea and Intestinal Inflammation in Undernourished Rats. BMC Gastroenterol. 2014, 5, 136. [CrossRef] [PubMed]

103. Bolick, D.T.; Kolling, G.L.; Moore, J.H., 2nd; de Oliveira, L.A.; Tung, K.; Philipson, C.; Viladomiu, M.; Hontecillas, R.; Bassaganya-Riera, J.; Guerrant, R.L. Zinc Deficiency Alters Host Response and Pathogen Virulence in a Mouse Model of Enteroaggregative Escherichia coli-induced Diarrhea. Gut Microbes 2014, 5, 618-627. [CrossRef] [PubMed] 
104. Vallee, B.L.; Falchuk, K.H. The Biochemical Basis of Zinc Pphysiology. Physiol. Rev. 1993, 73, 79-118. [PubMed]

105. Berni Canani, R.; Secondo, A.; Passariello, A.; Buccigrossi, V.; Canzoniero, L.M.; Ruotolo, S.; Puzone, C.; Porcaro, F.; Pensa, M.; Braucci, A.; et al. Zinc Inhibits Calcium-mediated and Nitric Oxide-mediated ion Secretion in Human Enterocytes. Eur. J. Pharmacol. 2010, 25, 266-270. [CrossRef] [PubMed]

106. Kloubert, V.; Rink, L. Zinc as a Micronutrient and its Preventive Role of Oxidative Damage in cells. Food Funct. 2015, 6, 3195-3204. [CrossRef] [PubMed]

107. Howell, G.A.; Welch, M.G.; Frederickson, C.J. Stimulation-induced Uptake and Release of Zinc in Hippocampal Slices. Nature 1984, 308, 736-738. [CrossRef] [PubMed]

108. Frederickson, C.J.; Koh, J.Y.; Bush, A.I. The Neurobiology of Zinc in Health and Disease. Nat Rev. Neurosci. 2005, 6, 449-462. [CrossRef] [PubMed]

109. Adamo, A.M.; Oteiza, P.I. Zinc Deficiency and Neurodevelopment: The case of neurons. Biofactors 2010, 36, 117-124. [CrossRef] [PubMed]

110. Ho, E.; Ames, B.N. Low Intracellular Zinc Induces Oxidative DNA Damage, Disrupts p53, NFkappa B, and AP1 DNA binding, and affects DNA Repair in a Rat Glioma Cell Line. Proc. Natl. Acad. Sci. USA 2002, 99, 16770-16775. [CrossRef] [PubMed]

111. Ramel, S.E.; Georgieff, M.K. Preterm Nutrition and the Brain. World Rev. Nutr. Diet. 2014, 110, $190-200$. [PubMed]

112. Zysman-Colman, Z.; Tremblay, G.M.; Bandeali, S.; Landry, J.S. Bronchopulmonary Dysplasia-Trends over three decades. Paediatr. Child. Health 2013, 18, 86-90. [PubMed]

113. Merritt, T.A.; Deming, D.D.; Boynton, B.R. The "new" bronchopulmonary dysplasia challenges and commentary. Semin. Fetal Neonatal. Med. 2009, 14, 345-357. [CrossRef] [PubMed]

114. Biniwale, M.A.; Ehrenkranz, R.A. The Role of Nutrition in The Prevention and Management of Bronchopulmonary Dysplasia. Semin. Perinatol. 2006, 30, 200-208. [CrossRef] [PubMed]

115. Prasad, A.S. Zinc is an Antioxidant and Anti-Inflammatory Agent: Its Role in Human Health. Front. Nutr. 2014, 1, 14. [CrossRef] [PubMed]

116. Wu, W.; Bromberg, P.A.; Samet, J.M. Zinc ions as effectors of environmental oxidative lung injury. Free Radic. Biol. Med. 2013, 65, 57-69. [CrossRef] [PubMed]

117. Bonaventura, P.; Benedetti, G.; Albarède, F.; Miossec, P. Zinc and its Role in Immunity and Inflammation. Autoimmun. Rev. 2015, 14, 277-285. [CrossRef] [PubMed]

118. McDonald, C.M.; Manji, K.P.; Kisenge, R.; Aboud, S.; Spiegelman, D.; Fawzi, W.W.; Duggan, C.P. Daily Zinc but Not Multivitamin Supplementation Reduces Diarrhea and Upper Respiratory Infections in Tanzanian Infants: A Randomized, Double-Blind, Placebo-Controlled Clinical Trial. J. Nutr. 2015, 145, 2153-2160. [CrossRef] [PubMed]

119. Beligere, N.; Perumalswamy, V.; Tandon, M.; Mittal, A.; Floora, J.; Vijayakumar, B.; Miller, M.T. Retinopathy of Prematurity and Neurodevelopmental Disabilities in Premature Infants. Semin. Fetal Neonatal. Med. 2015, 20, 346-353. [CrossRef] [PubMed]

120. Li, S.Y.; Fu, Z.J.; Lo, A.C. Hypoxia-induced Oxidative Stress in Ischemic Retinopathy. Oxid. Med. Cell. Longev. 2012, 2012. [CrossRef] [PubMed]

121. Yang, H.; Ding, Y.; Chen, L. Effect of Trace Elements on Retinopathy of Prematurity. J. Huazhong. Univ. Sci. Technolog. Med. Sci. 2007, 27, 590-592. [CrossRef] [PubMed]

122. Caulfield, L.E.; Zavaleta, N.; Shankar, A.H.; Merialdi, M. Potential Contribution of Maternal Zinc Supplementation during Pregnancy to Maternal and Child Survival. J. Clin. Nutr. 1998, 68, 499S-508S.

123. Anonymous. American Academy of Pediatrics Committee on Nutrition: Nutritional Needs of Low-birth-weight infants. Pediatrics 1985, 75, 976-986.

124. Committee on Nutrition of the Preterm Infant; European Society of Paediatric Gastroenterology and Nutrition. Nutrition and Feeding of Preterm Infants. Acta Paediatr. Scand. Suppl. 1987, 336, 1-14.

125. Zlotkin, S.H.; Atkinson, S.; Lockitch, G. Trace Elements in Nutrition for Premature Infants. Clin. Perinatol. 1996, 22, 223-240.

126. Klein, C.J. Nutrient requirements for preterm infant formulas. J. Nutr. 2002, 132, 1395S-1577S. [PubMed]

127. Hambidge, K.M.; Krebs, N.F.; Westcott, J.E.; Miller, L.V. Changes in Zinc Absorption during Development. J. Pediatr. 2006, 149, S64-S68. [CrossRef] [PubMed] 
128. Agostoni, C.; Buonocore, G.; Carnielli, V.P.; de Curtis, M.; Darmaun, D.; Decsi TDomellöf, M.; Embleton, N.D.; Fusch, C.; Genzel-Boroviczeny, O.; Goulet, O.; et al. Enteral nutrient supply for preterm infants: Commentary from the European Society of Paediatric Gastroenterology, Hepatology and Nutrition Committee on Nutrition. J. Pediatr. Gastroenterol. Nutr. 2010, 50, 85-91. [CrossRef] [PubMed]

129. Griffin, I.J.; Domellöf, M.; Bhatia, J.; Anderson, D.M.; Kler, N. Zinc and copper requirements in preterm infants: An examination of the current literature. Early Hum. Dev. 2013, 89, 29-34. [CrossRef] [PubMed]

130. Greene, H.L.; Hambidge, K.M.; Schanler, R.; Tsang, R.C. Guidelines for the use of vitamins, trace elements, calcium, magnesium, and phosphorus in infants and children receiving total parenteral nutrition: Report of the Subcommittee on Pediatric Parenteral Nutrient Requirements from the Committee on Clinical Practice Issues of the American Society for Clinical Nutrition. Am. J. Clin. Nutr. 1988, 48, 1324-1342. [PubMed]

131. Schanler, R.J.; Shulman, R.J.; Prestridge, L.L. Parenteral Nutrient Needs of very Low Birth Weight Infants. J. Pediatr. 1994, 125, 961-968. [CrossRef]

132. Higashi, A.; Ikeda, T.; Iribe, K.; Matsuda, I. Zinc Balance in Premature Infants Given the Minimal Dietary Zinc Requirement. J. Pediatr. 1988, 112, 262-266. [CrossRef]

133. Altigani, M.; Murphy, J.F.; Gray, O.P. Plasma Zinc Concentration and Catch up Growth in Preterm Infants. Acta Paediatr. Scand. Suppl. 1989, 357, 20-33. [CrossRef] [PubMed]

134. Marriott, L.D.; Foote, K.D.; Kimber, A.C.; Delves, H.T.; Morgan, J.B. Zinc, Copper, Selenium and Manganese Blood Levels in Preterm Infants. Arch. Dis. Child. Fetal. Neonatal. 2007, 92, 494-497. [CrossRef] [PubMed]

135. Pang, Y.; Applegate, T.J. Effects of Dietary Copper Supplementation and Copper Source on Digesta pH, Calcium, Zinc, and Copper Complex Size in the Gastrointestinal Tract of the Broiler Chicken. Poult. Sci. 2007, 86, 531-537. [CrossRef] [PubMed]

136. Smith, J.C., Jr. The Vitamin A-Zinc Connection: A review. Acad. Sci. 1980, 355, 62-74. [CrossRef]

137. Ahmed, F.; Barua, S.; Mohiduzzaman, M.; Shaheen, N.; Bhuyan, M.A.; Margetts, B.M.; Jackson, A.A. Interactions between Growth and Nutrient Status in School-age children of Urban Bangladesh. Am. J. Clin. Nutr. 1993, 58, 334-338. [PubMed]

(C) 2015 by the authors; licensee MDPI, Basel, Switzerland. This article is an open access article distributed under the terms and conditions of the Creative Commons by Attribution (CC-BY) license (http:/ / creativecommons.org/licenses/by/4.0/). 